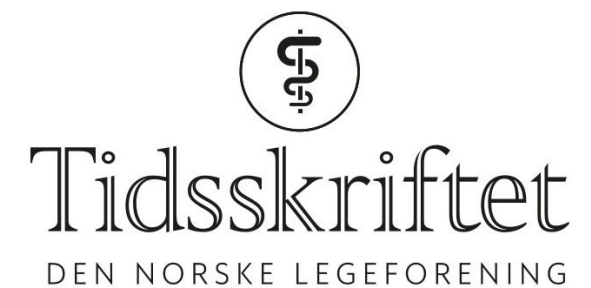

DEN NORSKE LEGEFORENING

\title{
Menneskelivets lykkeligste tid
}

TIDLIGERE I TIDSSKRIFTET

\section{JULIE DIDRIKSEN}

E-post: julie.didriksen@tidsskriftet.no Tidsskriftet

Da en skoledirektør i 1924 hevdet at dødeligheten var stor blant norske skolebarn, måtte Lorentz Harboe protestere. Statistikk er fandens bibel, mente han, for var det ikke egentlig slik at skolebarna tvert imot var blant de sunneste av barna? Hans erfaring var heller at "de kommer ind i 1ste klasse svake og fulde av mange skrøpeligheter," etter å ha overlevd de "lumske farer" i de første barneårene, før de "staar paa høiden av sin motstandskraft i 13 aars alder.” Under følger hans eksempler på hvordan statistikk kan brukes og misbrukes (Tidsskr Nor Lægeforen 1926; 46:183-7).

\section{Dødeligheten hos skolebarn.}

\section{Av L. Harboe, Hamar.}

Paa Nationalforeningens 7de raadsmøte i Bergen august 1924 holdt skoledirektør Efterstøl foredrag om skolebarnenes og ungdommens helse. Skoledirektøren uttaler her, at dødeligheten er stor blandt norske skolebarn og norsk ungdom. Jeg gaar ut fra, at der menes folkeskolens barn, naar talen er om skolebarn. Jeg er helt uenig med skoledirektøren, naar han uttaler, at dødeligheten er stor blant norske skolebarn. Det er ikke heldig, at det staar uimotsagt, og det kan let bli til et dogme, som gjør skade. Det er ikke heldig i vor nervøse tid, om den tro skal vokse sig fast, at vore skolebarn har en sørgelig stor dødelighet.

Naar man begynder at sysle litt med statistik, vil man snart opdage, at statistik er fandens bibel. Det er noget, som man ikke maa glemme. Jeg skal begynde med at citere, hvad der staar i dødelighetstabellerne for 1911-1920:

«Gjennemsnitsdødeligheten i ti-aaret var 13,77 pr. 1000 av den hjemmehørende middelfolkmængde; for en stationær tænkt befolkning derimot 17,52 pr. 10oo.» Denne lille oplysning er meget betegnende for statistik og viser, hvilket forskjellig resultat man kommer til ved den ene eller anden beregning. Begge resultater er i og for sig korrekte. Naar man skal sammenligne statistik fra forskjellige land, maa man være sikker paa, at der gaaes frem paa samme maate og efter samme metode. Det er en kjendsgjerning, at de forskjellige land har meget forskjellige regler at gaa efter. Naar man sammenligner Norge med øvrige land, maa man erindre, at sammenligningen er meget interessant, men den viser kun korrekthet med modifikation. Imidlertid la os gaa ut fra, at sammenligningen med andre land er brukbar.

I den overordentlig interessant idrætsbok av Løvland og Schiøtz, som enhver læge bør anskaffe og studere, er der paa side 3 en grafisk tabel over dødeligheten blandt smaabarn, 
skolebarn og ungdom, hvor Norge er sammenlignet med en række andre land. Kun to av disse tabeller gjælder skolebarn, nemlig 10 aars gutter og 10 aars piker. Her staar Norge som nr. 9 av 13 for gutternes vedkommende og som nr. 10 for pikerne. Hertil er først at bemerke, at denne statistik er forældet og gjælder for tiden 1901-1910. Dette gjør ogsaa dr. Schiøtz opmerksom paa. Meget kunde derfor ha talt for, at disse gamle tabeller ikke var tat med. De gir et feilagtig billede av Norge idag, og hvad der var aktuelt for 15 aar siden, har nu væsentlig historisk interesse.

Vi vil nu se nærmere paa statistik for 10 aaret 1911-20 sammenlignet med ældre perioder. For at gjøre forholdende saa enkle som mulig har jeg slaat sammen de fire aldersklasser 10, 11, 12 og 13 aar - svarende til folkeskolens øverste fire klasser.

Dode pr. tusen levende, alder 10, 11, 12 og 13 aar.

\begin{tabular}{c|c|c|c|c|c}
\hline \multicolumn{2}{c|}{ Gutter } & \multicolumn{3}{|c}{ Piker } \\
\hline Bygder & Byer & Oslo & Bygder & Byer & Oslo \\
\hline $\begin{array}{c}1881-1890 \\
4,5\end{array}$ & 4,8 & 4,8 & 4,7 & 5,5 & 6,4 \\
$1901-1910$ \\
$\begin{array}{c}2,9 \\
1911-1920 \\
2,66\end{array}$ & 3,41 & 3,39 & 3,33 & 3,8 & 3,68 \\
2,65 & 2,23 & 2,95 & 3,20 & 2,68
\end{tabular}

Vi ser, at der har været overordentlig stor fremgang fra ti-aaret 1881-9o. Der dør næsten kun halvparten i siste ti-aar mot for 30 aar siden. Vi maa dessuten erindre, at det siste ti-aar omfatter den ondartede influenza-epidemi i 1918, saa det er merkelig, at dødeligheten til trods herfor er saa ringe. Specielt staar Oslo udmerket. Dødeligheten i siste ti-aar for 12 aars alder er endog nede i 2,o8 for gutter. Jeg er ikke i tvil om, at sporten spiller her en stor rolle. Den styrker og hærder.

Det eneste land, hvor dødelighetstabellen foreligger for siste periode, er Holland. Sammenligningen ser saaledes ut:

\begin{tabular}{c|c|c|c|c}
\hline \multirow{2}{*}{$\begin{array}{c}\text { Alder } \\
10 \text { aar }\end{array}$} & \multicolumn{2}{|c|}{ Gutter } & \multicolumn{2}{|c}{ Piker } \\
\cline { 2 - 5 } & Holland & Norge & Holland & Norge \\
\hline \hline $1911-1920$ & 2,00 & 2,80 & 2,05 & 2,75
\end{tabular}

Holland har tidligere indtat en gunstig stilling med hensyn til dødelighet blandt skolebarn, og vi er kommet godt efter. Den brøkdel, som vi endnu er efter, kan godt tænkes indhentet ved f. eks. operativ behandling av appendiciter. Jeg ser med gru tilbake paa alle de dødsfald jeg hadde i gamle dager, da appendiciter enten ikke blev operativt behandlet eller for sent. Over store deler av landet staar adgangen til sykehus og operation aapen. Ialfald er det tilfældet her paa Østlandet, og jeg tviler ikke paa, at dette vil vise sin virkning paa statistiken for næste ti-aar.

Samtidig vil jeg omtale en anden form for statistik, som er i høi grad misvisende. Vore tuberkulosemænd fortæller, at f. eks. i 11-15 aars alder dør 40 pct. av tuberkulose. Tallet har sin relative interesse, men har liten værdi løsrevet fra sin sammenhæng. Det kan bedst paavises ved et eksempel. La os gaa ut fra en dødelighet hos skolebarn paa 3\%. Vi har altsaa 1000 barn, hvoav et tænkes død av tuberkulose og to av andre sygdommer. Der dør altsaa 33 pct. av tuberkulose. Ved forbedret hygiene vil vi tænke os, dødeligheten gaar ned til 2\%oen $\mathrm{d} ø \mathrm{r}$ av tuberkulose og en av anden sygdom. Tuberkulosemanden staar med taarer $\mathrm{i}$ øienene og konstaterer, at dødeligheten er steget til 50 pct. Ved end yderligere forbedring av hygienen faar vi dødeligheten ned til $1 \%$ - og den ene dør av tuberkulose. Nu er bægeret fuldt: 100 pct. dør av tuberkulose. La os saa tænke os et aar med en voldsom epidemi med mange dødsfald. Vi har en dødelighet av $6 \%$, hvorav fremdeles et dødsfald av tuberkulose. 
Tuberkulosemanden kan nu glæde sig over, at kun 16 pct. dør av tuberkulose. Den slags statistik bør helt forsvinde.

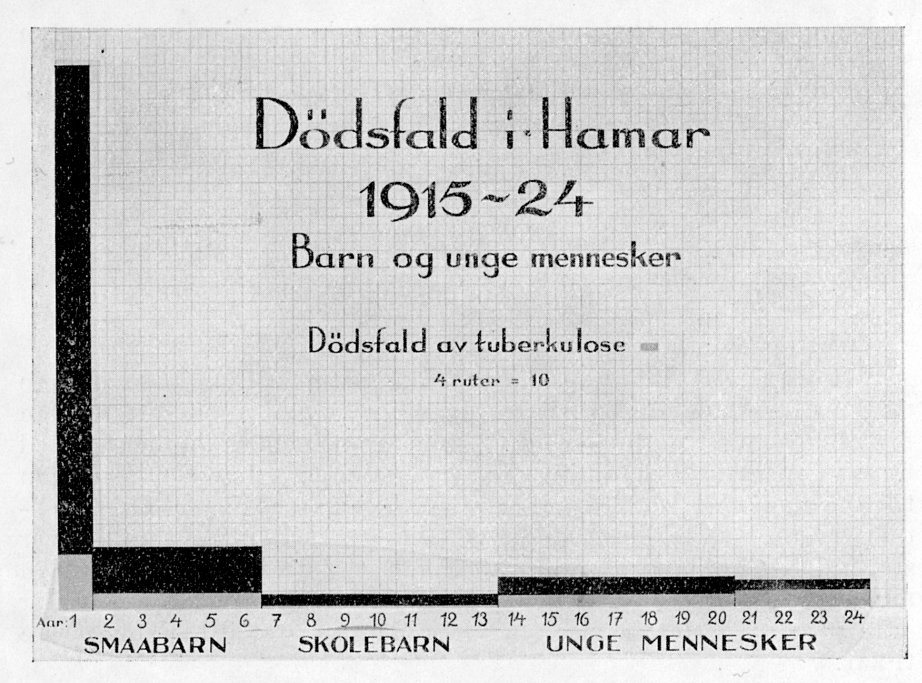

Jeg vil til slutning vise en grafisk fremstilling av dødsfald blandt barn og ungdom i Hamar det siste ti-aar. Det er ikke for at komme med tal, men kun for at vise, hvor merkelig gunstig de syv skoleaar staar i forhold til baade smaabarn-alderen og unge mennesker.

Gjennemsnitsdødeligheten er 2,5\% for skolebarn paa Hamar, altsaa nogen brøkdeler bedre end gjennemsnittet for det hele land. Hvis den samme lov skulde gjøre sig gjældende for skolebarn som for smaabarn og unge mennesker, vilde vi ha en dødelighet hos skolebarn paa mindst $6 \%$. Vi ser paa den grafiske kurve spedbarnsaaret som den høie isolerte søile. Saa har vi de fem smaabarnsaar med en forholdsvis stor dødelighet. Saa kommer de 7 skoleaar - menneskelivets lykkeligste tid, hvor døden er en sjelden gjest. Dødeligheten er kun en brøkdel av hvad den var i smaabarn-aarene. Saa har vi ungdoms-aarene til sist med større dødelighet. Min kurve er kun ført til 24 aars alder. At skolebarn-alderen har sin egen lov at gaa efter, ser jeg bl. andet av dødsfald ved epidemiske sygdommer. Mens smaabarnsalderen opviser her paa Hamar i ti-aaret hele $16 \mathrm{~d} ø \mathrm{~d}$ sfald av epidemiske sygdommer, har skolebarnsalderen intet. Jeg mener ikke, at skolebarnsalderen er forskaanet for dødsfald av epidemiske sygdommer. Mine tal gjælder kun et kort tidsrum i smaa forhold; men det er ganske merkværdig, at skolebarn greier den samme epidemi uten dødsfald, mens smaabarnsalderen har saa mange.

Man taler og skriver ofte om «les maladies de croissance». Ja, veksttiden har sine sygdommer; men man burde lægge mere vegt paa - for at fortsætte i det franske, «la croissante resistance des escoliers» - skolealderens økende motstandskraft likeoverfor sygdommer. Dette spørsmaal burde komme mere paa dagsorden og klarlægges. Mit indtryk av skolebarnene er, at de kommer ind i 1ste klasse svake og fulde av mange skrøpeligheter. Den første barnealder anser jeg for fuld av lumske farer. Er barnet kommet i 6 à 7 aars alder, er det kommet ind i mere smult farvand. I de følgende 7 skoleaar vokser barnet sig sterkere og sterkere og staar paa høiden av sin motstandskraft i 13 aars alder. Allerede fra 15 aars alder daler motstandskraften. Hvori denne $\emptyset$ kede motstandskraft bestaar, er ikke let at si.

Paa den grafiske kurve har jeg fremstillet tuberkulosen med lysere farve. Vi ser, hvorledes tuberkulosen spiller en liten rolle i skoleaarene. De fleste barn i 1ste klasse bærer merker av gjennemgaatte infektioner. Jeg har notert for de fleste barn «hovne halsglandler», «hovne nakkeglandler». Hvor stor del av disse skyldes tuberkulosen, kan ingen vite; men den bærer vel skylden for en stor del. Imidlertid er en utviklet lungetuberkulose i skolealderen meget sjelden. De tuberkuløse ledlidelser er den største sjeldenhet; tuberkuløse meningiter likesaa. Ogsaa for tuberkulosens vedkommende er skolealderen noget av en oase. I forhold til smaabarnsalderen og likeledes til ungdomsalderen staar skolebarnsalderen i en særstilling. Naar jeg hilser den metodiske undersøkelse av skolebarn med glæde, er det ikke, fordi jeg derigjennom har haab om at finde manifeste tuberkuloser, som kan tages i tide. Saadanne tilfælder vil være forholdsvis sjeldne. Den store betydning ligger i at hæve 
barnenes almindelige hygiene. Infektionsprofylaksen tilhører smaabarnsalderen.

Dispositionsprofylaksen har vi at arbeide med i skolen. Og da barnets fysiologiske utvikling fra 1ste klasse til 7 de klasse peker i retning av fra det svakere til det sterkere, vil vort arbeide være taknemmelig. Vi arbeider saa at si i medvind.

Disse linjer er ikke skrevet som et angrep paa de høit fortjente mænd, som har slaat et slag for skolens forbedrede hygiene. Det være langt fra. Jeg har kun villet komme med min opfatning av skolebarnenes forhold til sygdom og død. Og da jeg maaske staar noksaa alene om denne opfatning, har jeg forsøkt at begrunde min mening.

Publisert: 21. august 2017. Tidsskr Nor Legeforen. DOI: 10.4045/tidsskr.17.0541

(C) Tidsskrift for Den norske legeforening 2020. Lastet ned fra tidsskriftet.no 